\title{
Financial Management, Organizational Commitment and Legislative Role on the Implementation of Good Governance at Village Governments
}

\author{
YESI MUTIA BASRI \\ LEDIA ZURNI ARFENDI \\ NUR AZLINA \\ Accounting Department, University of Riau
}

\begin{abstract}
This research aims to determine the effect of village financial management, organization commitment, and role of the village representative board on the implementation of good village governance on village government in Siak Regency. This research used primary data gathered by using a questionnaire and was conducted in 2020. The population in this research was the village government in Siak Regency which totaled 122 villages, with respondents consisting of the village head, village secretary, head of financial officer, and the head of the village representative board. The sampling technique of this research was proportional stratified random sampling, with a total sample obtained by 27 village governments, with a total of 108 respondents. The data analysis method in this research is the multiple regression analysis with the program of Statistical Package for Social Science (SPSS) v.25. This research indicated that village financial management, organizational commitment, and the village representative board's role have a positive and significant influence on the implementation of good village governance.
\end{abstract}

Keywords: Governance, Village Financial, Commitment

Abstrak: Penelitian ini bertujuan untuk mengetahui pengaruh pengelolaan keuangan desa, komitmen organisasi, dan peran Badan Permusyawaratan Desa (BPD) terhadap penerapan good village governance pada Pemerintah Desa di Kabupaten Siak. Penelitian ini menggunakan data primer dengan kuesioner dan dilakukan pada tahun 2020. Populasi dalam penelitian ini adalah Pemerintah Desa di Kabupaten Siak yang berjumlah 122 Desa, dengan responden yang terdiri dari Kepala Desa, Sekretaris Desa, Kepala Urusan Keuangan, dan Ketua Badan Permusyawaratan Desa. Teknik pengambilan sampel yang digunakan dalam penelitian ini adalah Proportional Stratified Random Sampling, dengan jumlah sampel yang diperoleh sebanyak 27 pemerintah desa, dengan jumlah responden sebanyak 108 orang responden. Metode analisis data yang digunakan dalam penelitian ini adalah analisis regresi berganda dengan menggunakan program Statitical Package for Social Science (SPSS) v.25. Hasil penelitian menunjukkan bahwa pengelolaan keuangan desa, komitmen organisasi, dan peran Badan Permusyawaratan Desa (BPD) memiliki pengaruh positif dan signifikan terhadap penerapan good village governance.

Kata Kunci: Governance, Keuangan Desa, Komitmen.

*Corresponding author: nur.azlina@ lecturer.unri.ac.id 


\section{Introduction}

Law number 6 of 2014 concerning Villages is a turning point in village regulations in Indonesia. Villages become autonomous regions given special rights to administer their government. This law regulates how to run village governance and village development so that if the village government has implemented this law in its administration, good governance can be created.

Good governance is implementing a reliable and responsible, efficient, and effective government while maintaining a synergy of constructive interactions between the state, private, and community domains. UNDP believes that the principles that must be adhered to and developed in good governance practices include participation, law enforcement, transparency, consensus orientation, justice, effectiveness and efficiency, accountability, and strategic vision. The nine principles are mutually reinforcing and cannot stand alone (LAN, 2008).

The Worldwide Governance Indicators (WGI) states that six indicators create the level of government in a country, including accountability, political stability and terrorism, government effectiveness, quality of rules, legal principles, and Collusion, Corruption, and Nepotism. The six indicators will provide a portrait of a country's governance. In WGI's research, the value of the six indicators of Indonesian governance in 2017 is still low (score below 60), with details of the value per component in a row being 48 for control of corruption, 54 for government effectiveness, 29 for political stability and absence of violence/terrorism, 52 for regulatory quality, 41 for the rule of law, and 51 for voice and accountability (Kemenkeu, 2019).

According to Kuswanto (2016), Good governance in Indonesia is far from successful. The number of corruption cases, misappropriation of policies, and public services that make it difficult for the public is proof that the implementation of Good Governance in Indonesia has not been well ordered. This is also supported by the Indonesia Corruption Watch (ICW) evaluator, which found corruption cases in Indonesia during the first semester of 2020, 1,043 defendants were tried at various court levels. Village officials were the sector that committed the most acts of corruption, namely 263 people, then the state civil apparatus 222 people, and the private sector 198 
people (Harjanto, 2020). Weak good governance in the village government in Riau Province is found in villages in Siak District. The findings from the results of the investigation by the team from the Independent Monitoring Agency for Corruption Crime stated that there was an alleged mark-up of village funds in 2019 in the construction of drainage carried out by the Head of Pangkalan Makmur Village, Dayun District, Siak Regency.

Furthermore, according to reports from the community, the lack of transparency in the realization of allocation of village funds in Pangkalan Makmur village was due to a lack of supervision from the authorities (Tabirnews.com, 2019). The above case shows the importance of implementing good governance in village governance. Government administration and development in village governments can appropriately, cleanly, responsibly, and free from corruption, collusion, and nepotism. Thus, it will make good governance in the village government. Good governance impacts minimizing the occurrence of fraud and impacting organizational performance (Taufik, 2019; In'airat, 2015). Therefore it is clear that the implementation of good governance in the government cannot be postponed any longer.

Previous research has examined various factors that influence the successful implementation of good governance in the public sector and have been investigated by several researchers (Supratman, 2018). One of the factors that influence the implementation of good governance in the government is the management of government finances. May (2016) conducted a study on the effect of government financial management on the implementation of good governance in the local government of Sleman Regency. The results of his research indicate that financial management affects good governance. Likewise, Ristanti et al. (2014) show that financial management affects good governance in the Tabanam regency government. Research of Setiawan (2018) also shows that management of village funds can increase the transparency of accountability and participation.

No less critical for the successful implementation of good governance is organizational commitment. According to Robbins (2009), organizational commitment is a condition where an employee side with a particular organization and its goals and 
desires to maintain membership in the organization. High individual involvement in a job shows siding with the organization. Therefore, a strong commitment from members of the organization can determine the successful implementation of good governance. This is confirmed by research conducted by Rantelangi et al. (2018) and Syam \& Zubaidah (2014), which states that organizational commitment affects the implementation of good governance.

The legislative role is also one that can influence the implementation of good governance in the government. The legislature plays a vital role in bringing about democratic governance (Sayuti, 2016). In the village government, the legislative role is played by the Village Consultative Board. According to Law Number 6 of 2014 concerning Villages, the Village Consultative Board carries out government functions whose members are representatives of the Village population-based on regional representation and are determined democratically. Following the duties and functions of the Village Consultative Board, namely as an institution that carries out the legislative function, accommodates the aspirations of the community, and carries out the supervisory function, it is hoped that the effective implementation of this function can be achieved with a balance of power between the elements of society represented by the Village Consultative Board and the village government, so that can create good governance in the village government. This is in line with (Helmayani et al., 2017) and (Hartati, 2018), which shows that the Village Consultative Board has a role in encouraging good governance in the village.

Research on the implementation of good governance is mostly carried out in local governments example, Lamangida (2018); Ayub. et al. (2018); Ahmad \& Rosmiati (2019); Rantelangi et al. (2018), and only a few are studying it at the village government. Therefore this research was conducted at the village government. The successful implementation of good governance in village governments can reduce corruption that often occurs in village governments.

Helmayani conducted previous research on good governance in village government. et al. (2017) examined the influence of human resource competence and the Village Consultative Board's role in Buleleng Regency. This study develops this research using 
village financial management variables. The importance of financial management in creating good governance was previously studied by Setiawan (2018) at villages in the Sukoharjo Regency, which shows that the management of village funds can increase the transparency of accountability and community participation. Research of May (2016) shows that financial management can realize good governance in local governments.

This study aims to examine the effect of village financial management, organizational commitment, and the role of the legislature on the implementation of good governance in village government in Siak Regency. This research has a contribution in realizing good governance in village government.

\section{Theoretical Framework and Hypothesis Development}

\subsection{Agency Theory}

In practice, agency theory has a contractual relationship between principals and agents (Jansen and Smith, 1984). In public sector organizations, the principal means the people, and the agent is the government, in this case, the village head and other officials. Government Regulation Number 71 of 2010 concerning Government Accounting Standards explains the clear relationship between agency theory and accountability. Accountability is the duty of the agent / in this case, the village head, and its officials to provide accountability, present, report, and confirm all activities and activities that are their responsibility to the principal who has the right and authority to ask for this accountability, accountability is the keyword for good village governance.

\subsection{Stewardship Theory}

Stewardship theory explains how management is not motivated by individual goals but motivated by organizational interests as the primary goal (Donaldson, 1991). The philosophical assumptions of this theory are based on human characteristics in the form of being trustworthy, having integrity, being responsible for every action, and being honest with all parties. Stewardship theory illustrates that management can behave well to benefit many parties to create a strong relationship between organizational satisfaction and success. The implication of the Stewardship theory in this research is to describe the existence of the village government as a trustworthy public sector 
organization, accommodate the aspirations of the community, provide good service, and be accountable for what is entrusted to it. So that with the commitment that the village government apparatus has in fulfilling the organizational goals for the welfare of the community, it can be achieved optimally.

\subsection{The Effect of Village Financial Management on the Implementation of Good}

\section{Governance}

According to Law number 6 of 2014 article 71 (1), village finances are all village rights and obligations that can be assessed in money and everything in the form of money and goods related to the implementation of village rights and obligations. Village financial management, according to Regulation of the Minister of Home Affairs 20 of 2018 concerning village financial management, is all activities that include planning, implementation, administration, reporting, and village financial accountability.

Regulation of the Minister of Home Affairs 113 of 2014 and Regulation of the Minister of Home Affairs 20 of 2018 concerning Village Financial Management states that village finances must be managed based on transparency, accountability, participation, and carried out in an orderly and disciplined budget. If village financial management has been carried out well and applies management principles following these regulations, it will realize good governance principles. Prior studies (Ristanti et al., 2018; Setiawan, 2018; May 2016) have researched financial management. Their research results indicate that regional financial management has a significant effect on the implementation of good governance. Based on the description above, the following hypothesis can be formulated:

H1: Village Financial Management has a positive effect on the implementation of good governance.

2.4 The Effect of Organizational Commitment on the Implementation of Good Governance.

According to Luthans (2006), organizational commitment is a strong desire that employees have to maintain their position as a member of the organization where they work, the desire to strive to be part of the organization, and a strong belief in acceptance of the values and goals that exist in the organization. Organizational commitment is 
more than just passive loyalty and involves active relationships and an individual's personal desire to contribute fully to the organization. Organizational commitment is an encouragement for someone to work better; thus, the village government will be even better at implementing good governance in the region.

Sopiah (2008) argued that organizational commitment has three factors: strong trust and acceptance of organizational goals and values, readiness to work hard, and a strong desire to survive. This commitment is classified as an attitude because it relates to the level of an individual's assessment of the extent to which the individual feels that personal values and goals are following the values and goals of the organization.

Village government managers are village heads assisted by village officials who must be people who have a high commitment to advancing the village. The village's strong commitment to advance the village will encourage good governance because they work sincerely to achieve village welfare. Prior studies in an organizational commitment by (Ristanti et al., 2014) and (Mada et al., 2017) found that government officials' strong commitment can create good governance in government. Based on the description above, the following hypothesis can be formulated.

H2: Organizational commitment has a positive effect on the implementation of good governance.

\subsection{The Effect of the Role of the Legislative on the Implementation of Good Governance.}

The legislature in the village government is organized by the Village Consultative Board, which plays a role in overseeing the village government. Following its duties and functions, namely, as an institution that carries out the legislative function, accommodates the aspirations of the community, and carries out the supervisory function, it is hoped that the effective implementation of these functions can create a balance of power between the elements of society represented by the Village Consultative Board and the village government so that governance can be created good governance. Research on the Village Consultative Board's role has been conducted previously by (Helmayani et al., 2017) and (Hartati, 2018), which shows that the Village Consultative Board has a role in encouraging the creation of good governance in the village. Based on the description above, the following hypothesis can be formulated: 
H3: The legislative role has a positive effect on the implementation of good governance.

\section{Research Method}

\subsection{Population and Sample}

The population used in this research is the Village Government in Siak Regency, amounting to 122 villages. The sampling technique used was Proportional Stratified Random Sampling. The sampling stage was carried out by taking the ten highest building village index numbers from each village category. However, there are exceptions for the independent and underdeveloped village category because it does not reach ten villages. We decided to take the entire population in that village category to be the sample in this study. The number of samples in this study was 27 villages in Siak Regency.

Respondents in this study were the Village Head, Village Secretary, Head of Financial Affairs, and the Head of the Village Consultative Body. The total number of respondents in this study was 108 people. The data collection technique used in this study is by sending a questionnaire directly to the respondents in this study. Data analysis in this study uses multiple regression analysis using the Statistical Package for Social Science (SPSS) program version 25.

\subsection{Operational Definition and Variable Measurement}

The variables were grouped into four, namely, dependent variable and independent variable. Good governance was the dependent variable. Meanwhile, the independent variable involved Village financial management, organizational commitment, and the Village Consultative Board's role. The operational definition and measurement of each variable are described :

a. Good Village Governance

The good governance variable's measurement uses the instruments used in the study

(Ristanti et al., 2014). This variable is measured by a 5-point Likert scale consisting of 8 indicators: community participation, responsiveness, the rule of law, 
effectiveness and efficiency, justice, consensus-oriented, accountability, and transparency.

b. Village financial management

The variable Village financial management measurement uses the instruments used in the study by Sukmawati \& Nurfitriani (2019). This variable is measured by a 5point Likert scale consisting of 5 indicators: Village Financial Planning, Village Financial Implementation, Village Financial Administration, Village Financial Reporting, and Village Financial Accountability.

c. Organizational Commitment

The variable Organizational commitment measurement uses the instruments used in the study by Sopiah (2008). This variable is measured by a 5-point Likert scale consisting of 3 indicators, affective commitment, normative commitment, and sustainable commitment.

d. The Village Consultative Board

The variable Organizational commitment measurement uses the instruments used in the study by Helmayani et al. (2017). This variable is measured by a 5-point Likert scale consisting of 5 indicators, namely agreeing on the draft village regulation, monitoring the performance of the village head, channeling community aspirations.

\section{Results and Discussion}

\subsection{Descriptive Data}

Of the 108 questionnaires distributed, 88 questionnaires returned (81.5\%) and 20 questionnaires that did not respond (18.5\%). Eighty-eight questionnaires can be processed further or $(81.5 \%)$ of the total questionnaires sent. Descriptive statistical test results can be seen from the mean, standard deviation, variance, maximum, minimum, sum, range, kurtosis, and skewness (Ghozali, 2013)(Ghozali, 2013:19). 
Tabel. 1

Descriptive Statistics

\begin{tabular}{lccccc}
\hline Items & $\mathrm{N}$ & Minimum & Maximum & Mean & Std. Deviation \\
\hline Village Fin. Mgt & 88 & 29.00 & 45.00 & 37.7841 & 3.57015 \\
Org. Commitment & 88 & 34.00 & 60.00 & 49.8864 & 4.68412 \\
Legislative Role & 88 & 31.00 & 45.00 & 37.8409 & 3.27613 \\
Implement. of GG & 88 & 29.00 & 45.00 & 37.9659 & 3.23575 \\
\hline
\end{tabular}

Source: Data processed by SPSS 25.0, 2020

The data (Table 1) shows that the standard deviation value does not exceed the average, which indicates good data from the descriptive statistical analysis test results.

\subsection{Validity and Reliability Test}

Based on the statistical analysis conducted using SPSS software version 25, the validity test demonstrates that the correlation between the independent variables perception of village financial management, organizational commitment, legislative role, and the dependent variable of implementation of good governance are all valid since correlation value is more extensive than $r$ table used in this study, which is 0,194 . Hence, each item in the questionnaire employed in this study is valid for reliability. Based on the results of data reliability testing for all variables in this study, the results of Cronbach's alpha were above 0.7, which means that the data is reliable and can be continued in subsequent processing. It means that the variables used are consistent and reliable (Ghozali, 2013).

\subsection{Coefficient of Determination $\left(R^{2}\right)$}

The coefficient of determination aims to measure the mode's ability to explain the dependent variable's variance. The value of the coefficient of determination is between zero and one. If $\mathrm{R}^{2}$ is small, the ability of independent variables to explain the variance of the dependent variable is limited. The value which is close to one means that the independent variables give almost all information needed to predict the variance of the dependent variable. Table 2 shows that the adjusted $\mathrm{R}$ square value is 0.926 . This means that the contribution of the influence of the independent variable to the dependent variable is $92.6 \%$. In comparison, the remaining $7.4 \%$ is influenced by other variables not included in this regression model. 
Table 2.

Model Summary b

\begin{tabular}{lccc}
\hline Model & $\mathrm{R}$ & R Square & Adjusted R Square \\
\hline 1 & $0.964^{\mathrm{a}} \mathrm{a}$ & .929 & .926
\end{tabular}

Source: Data processed by SPSS 25.0, 2020

Testing the research variables using multiple linear regression analysis is intended to determine the effect of village financial management, organizational commitment, and legislative role on implementing good governance.

Table 3.

Coefficients

\begin{tabular}{|c|c|c|c|c|c|c|}
\hline \multirow[t]{2}{*}{ Model } & \multicolumn{2}{|c|}{$\begin{array}{l}\text { Unstandardized } \\
\text { Coefficients }\end{array}$} & \multirow{2}{*}{$\begin{array}{l}\text { Standardized } \\
\text { Coefficients } \\
\text { Beta }\end{array}$} & \multirow[t]{2}{*}{$\mathrm{T}$} & \multirow[t]{2}{*}{ Sig. } & \multirow[t]{2}{*}{ Result } \\
\hline & $\mathrm{B}$ & Std. Error & & & & \\
\hline$\overline{\text { (Constant) }}$ & 2.181 & 1,108 & & 1.968 & .052 & \\
\hline Village Fin. Mgt & .324 & .049 & .357 & 6,666 & .000 & Supported \\
\hline Org. Commitment & .219 & .059 & .317 & 3,745 & .000 & Supported \\
\hline Legislative Role & .333 & .088 & .338 & 3,770 & .000 & Supported \\
\hline
\end{tabular}

a. Dependent Variable: Implementation of Good Governance

Source: Data processed by SPSS 25.0, 2020

From table 3, the results of the regression equation can be determined as follows: $Y$ $=\alpha \mathrm{Y}=2,181+0,324 \mathrm{X} 1+0,219 \mathrm{X} 2+0,333 \mathrm{X} 3+\mathrm{e}$

\subsection{Discussion of Hypothesis TestingResults of testing hypothesis 1}

\subsubsection{The Effect of Village Financial Management on the Implementation of Good Governance}

In table 3, it can be seen that the effect of village financial management (X1) on the implementation of good governance $(\mathrm{Y})$ has a significance value of $0.000<0.05$ with a value of $\beta 0.324$, which indicates that village financial management has a significant positive effect on the implementation of good governance. So it can be concluded that $\mathrm{H}_{1}$ is accepted; namely, Village Financial Management has a positive effect on the Implementation of Good Governance. This shows that the better the financial management of the village government, the better the implementation of good governance in the village government in Siak District. 
According to the Regulation of the Minister of Home Affairs Number 20 of 2018 concerning village financial management, it explains that village financial management is all activities that include planning, implementation, administration, reporting, and village financial accountability. Village finances must be managed based on transparent, accountable, participatory principles and carried out in an orderly and disciplined budget.

According to Law 6 of 2014 concerning Villages, in article 77 paragraph (1), (2), and (3), it is explained that the management of village property is carried out based on the principles of public interest, function, legal certainty, openness, efficiency, effectiveness, accountability, and certainty of economic value. The management of village-owned wealth is carried out to improve the welfare and standard of living of the Village community and improve the welfare and standard of living of the Village community and increase Village income. As referred to in paragraph (2), the management of Village-owned assets is discussed by the Village Head and the legislative based on the procedures for managing village-owned assets, which are regulated in a Government Regulation. Suppose village financial management has been implemented properly. In that case, it can realize the principles of good governance itself because the principles in village financial management are in line with the principles of good governance, namely the principles of transparency, accountability, and participation. This is supported by the existence of agency theory where accountability is needed from the agent or, in this case, the village head and officials to provide accountability, present, report, and confirm all activities and activities of village financial management, which are the responsibility of the principal who has the right and the authority to ask for this accountability, accountability is the keyword for the good governance of local (village) government.

This is in line with the previous research conducted by (Sukmawati \& Nurfitriani, 2019), which shows that regional financial management has a positive and significant effect on implementing good governance. This means that the better the institution's financial management, the better the implementation of good governance in that institution. 


\subsubsection{The Effect of Organizational Commitment on the Implementation of Good Governance}

In table 3 , it can be seen that the effect of organizational commitment (X2) on the implementation of good governance $(\mathrm{Y})$ has a significance value of 0.000 . The significance value $(0.000)<0.05$ with a coefficient value of $\beta 0.219$ indicates that organizational commitment positively affects the implementation of good governance. Therefore, it can be concluded that $\mathrm{H}_{2}$ is accepted; namely, Organizational Commitment has a positive and significant effect on the Implementation of Good Governance, which means that the higher the organizational commitment, the better its implementation in the village government Siak Regency.

According to Luthans (2006), organizational commitment is a strong desire that employees must maintain their position as a member of the organization they work for, a desire to try to be part of the organization, and a strong belief in the acceptance of the values and goals that exist in the organization. The three main characteristics of organizational commitment are a strong belief in the organization towards the goals and values of the organization (identification), a strong desire to maintain strong relationships within the organization (loyalty), and readiness and availability to work and endeavor for the benefit of the organization. Organizational commitment is more than just passive loyalty and involves active relationships and an individual's personal desire to make a full contribution to the organization. Organizational commitment is an encouragement for someone to work better so that the village government will be better at implementing good governance in their area. This is supported by the stewardship theory that explains the situation in which the management, in this case, the village head and other village government officials, is not motivated by individual goals but is motivated by the interests of the village government and public services to the community as the primary goal because of the high commitment each village apparatus has in working for the progress of their village.

This is in line with the results of previous research conducted by (Ristanti et al., 2014), which shows that organizational commitment has a positive and significant effect 
on implementing good governance. This means that the higher the organizational commitment of an employee, the better the implementation of good governance in the agency will be.

\subsubsection{The Effect of the Role of legislative on the Implementation of Good Governance.}

In table 3, it can be seen that the effect of the legislative role (X3) on the implementation of good governance $(\mathrm{Y})$ has a significance value of 0.000 . The significance value $(0,000)<0.05$ with a coefficient $\beta$ of 0.333 means that the legislative role has a positive effect on implementing good governance. So it can be concluded that $\mathrm{H}_{3}$ is accepted; namely, the role of the legislature has a positive and significant effect on the implementation of good governance, which means that the better the role of the legislature, namely the Village Consultative Board, the better the implementation of good governance in the Village Government of Siak district.

The Village Consultative Board is a legislative institution at the village level that participates in discussing and agreeing on various policies in the implementation of village government. The Village Consultative Board, as a legislative institution at the village level, has duties and functions based on Law Number 6 of 2014 concerning Villages. The Village Consultative Board aims to accommodate and channel community aspirations to the village government through the official village planning and development forum or other informal forums.

Concerning village funds, the role of the legislature is vital because all validations related to the village fund budget, including the formulation of the APBDes, must go through legislative validation. In this case, the Village Consultative Board must carry out its role and function so that the allocation of village funds can be appropriately managed and is beneficial to community needs by making the community the subject of development.

In line with attitude and behavior theory, Ajzen, Al Sugiri (2015) explains legislative independence. Suppose the Village Consultative Board, as legislative and other village officials in managing village finances, does not appear independent and transparent. In that case, users of financial reports will increasingly distrust the village 
apparatus's financial reports, and the opinions produced by auditors regarding audited financial reports are of no value. Therefore, the behavior of the legislative as supervisors in village development and village officials as implementers in the context of village financial management. Both of these must be able to work together in contributing to correct and clean village financial management. The current government is focused on village development, which must be optimized to take the best oversight of village financial management. Also, the function of the legislative as a supervisor, supervising the implementation of village government, can be an instrument of good village governance so that the implementation of good governance in the village government can run well. The research results support Helmayani et al. (2017), which shows that the role of the legislature has a significant effect on the implementation of good village governance.

\section{Conclusion, Implication, and Limitation}

Based on the results of the research and discussion previously described, the conclusions that can be drawn from this study are village financial management, organizational commitment, and the role of the legislature have a positive and significant effect on the implementation of good governance in the village government in Siak Regency, meaning the better financial management village, the higher the level of organizational commitment possessed by village government officials, and the better the legislative role, in this case, the village consultative body, the better the implementation of good governance in the village government in Siak Regency.

This study has several limitations that may affect the study results. These limitations include the sample used in this study with the minimum number of samples needed. However, this study will produce better data if submitted to a larger population and sample. This study has limitations on the analytical tool because it does not directly test the indicators so that further research can use analysis tools such as PLS. This study only uses village financial management variables, organizational commitment, and legislative roles so that there may be other variables that influence the implementation of good governance in village governments that need to be investigated. 
The results of this research have implications for strengthening and developing public sector accounting theory and the same previous research. In the framework of agency theory, the agent's accountability, in this case, is the village government, namely providing accountability, presenting, reporting, and confirming all activities and activities that are their responsibility to the principal, in this case, the village community who has rights and authority to hold that accountability. Within the framework of the stewardship theory, the motivation of village government officials who prioritize the interests of many parties, in this case, is for the progress of the village, which can be manifested by the high commitment of each village apparatus in the context of administering governance in the village. Furthermore, in the theoretical framework of attitudes and behaviors that highlight the attitude of independence, this is manifested by the behavior of the BPD as supervisors in village development and village officials who run the wheels of government. Both of these must contribute to the village's progress and the creation of good government governance or what is often referred to as good governance.

The practical implication, the village government, can be more aware that village financial management, organizational commitment, and the Village Consultative Body's role can influence the governance of the village government so that it can be taken into consideration in all aspects, including in decision making. The results of this study are also expected to provide input to the village government, particularly to take strategic steps to improve governance in the village so that good governance can be achieved.

\section{Reference}

Ahmad, F. M., \& Rosmiati, M. (2019). Analisis Manajemen Risiko Dalam Mewujudkan Good Governance pada pemerintah Kabupaten Bandung Barat. Polban, 1182-1192.

Ayub, R. D., Suyana Utama, M., \& Wardana, I. G. (2018). Analisis Faktor-Faktor Yang Mempengaruhi Penerapan Good Governance Pada Pemerintah Provinsi Bali. E-Jurnal Ekonomi Dan Bisnis Universitas Udayana, 4, 987. https://doi.org/10.24843/eeb.2018.v07.i04.p03

Ghozali, I. (2013). Aplikasi Analisis Multivariete. BPFE Universitas Diponegoro. 
Hartati, R. (2018). Optimalisasi Fungsi Badan Permusyawaratan Desa (BPD) Dalam Mewujudkan Prinsip Good Governance (Studi di Kabupaten Pangandaran). Jurnal Moderat, 534(4), 114-123.

Helmayani, P. L., Sulindawati, N. L. G. E., \& Dewi, P. E. D. M. (2017). Pengaruh Kompetensi Sumber Daya Manusia, Peran Badan Permusyawaratan Desa, Dan Partisipasi Masyarakat Terhadap Implementasi Good Village Governance (Studi Pada Desa Di Kabupaten Buleleng). JIMAT (Jurnal Ilmiah Mahasiswa Akuntansi S1), 8(2). https://doi.org/10.23887/jimat.v8i2.13298

In'airat, M. (2015). The Role of Corporate Governance in Fraud Reduction-A Perception Study in the Saudi Arabia Business Environment. Journal of Accounting and Finance, 15(2), 119.

Kuswanto, G. (2016). Pelaksanaan Good Governance di Indonesia. In Http://Berita.KnkgIndonesia.Org (p. 8). http://berita.knkg-indonesia.org/2016/11/pelaksanaan-goodgovernance-di-indonesia.html

Lamangida, T. (2018). Studi Implementasi Good Governance Pemerintahan Daerah Kabupaten Bone Bolango. Publik: (Jurnal Ilmu Administrasi), 6(2), 119. https://doi.org/10.31314/pjia.6.2.119-126.2017

Mada, S., Kalangi, L., \& Gamaliel, H. (2017). Pengaruh Kompetensi Aparat Pengelola Dana Desa, Komitmen Organisasi Pemerintah Desa, dan Partisipasi Masyarakat Terhadap Akuntabilitas Pengelolaan Dana Desa Di Kabupaten Gorontalo. Jurnal Riset Akuntansi Dan Auditing “Goodwill,” 8(2), 106-115. https://doi.org/10.35800/jjs.v8i2.17199

May, R. (2016). Pengaruh Sistem Pengendalian Internal Pemerintah (SPIP), Pengelolaan Keuangan Daerah, Komitmen Organisasi dan Budaya Organisasi terhadap Penerapan Good Governance. UPN Veteran Yogyakarta.

Rantelangi, C., Affan, N., Deviyanti, D. R., \& I R Sari, W. (2018). The Influence of Organizational Commitment, Auditor Independence, Internal Control, and Ethical Leadership in Good Governance and Organizational PerformanceGood Governance and Organizational Performance. 35(Miceb 2017), 236-242. https://doi.org/10.2991/miceb-17.2018.36

Ristanti, N. M. A., Sinarwati, N. K., \& Sujana, E. (2014). Pengaruh Sistem Pengendalian Intern, Pengelolaan Keuangan Daerah Dan Komitmen Organisasi Terhadap Penerapan Good Governance. Jurnal Akuntansi, 2(1), 1-11.

Sukmawati, F., \& Nurfitriani, A. (2019). Pengaruh Transparansi dan Akuntabilitas terhadap Pengelolaan Keuangan Desa ( Studi pada Pemerintah Desa di Kabupaten Garut ). Jurnal Ilmiah Bisnis, Pasar Modal, Dan UMKM, 2(1), 52-66.

Syam, D., \& Zubaidah, S. (2014). Organisasional Manajer, dan Pengendalian Internal Terhadap Penerapan Prinsip-Prinsip Good Corporate Governance. 4(2), 647-656. 
The Indonesian Journal of Accounting Research - Jan, Vol. 24, No.1 , 2021

Taufik, T. (2019). The effect of internal control system implementation in realizing good governance and its impact on fraud prevention. International Journal of Scientific and Technology Research, 8(9), 2159-2165. 